\title{
Language Barrier And The Performance of Secondary School Students in EnglishLanguage in Katsina Metropolis
}

\author{
Nwabudike, Christopher Eziafa (Corresponding author) \\ Department of English Language and Communications, Federal University, Dutsinma, P.M.B 5001, Katsina State, Nigeria \\ E-mail: cnwabudike@fudutsinma.edu.ng \\ Ojoko, E. A. \\ Department of Agricultural Economics and Extension, Federal University, Dutsinma, P.M.B 5001, Katsina State, Nigeria \\ George Anaso Nwaorah \\ Department of English Language and Communications, Federal University, Dutsinma, P.M.B 5001, Katsina State, Nigeria
}

Received: 07-04-2014

doi:10.7575/aiac.ijalel.v.3n.5p.206
Accepted:16-05-2014

Published: 01-09-2014

URL: http://dx.doi.org/10.7575/aiac.ijalel.v.3n.5p.206

\begin{abstract}
This research work centres on Language Barrier and the Performance of Secondary School Students in English Language in Katsina Metropolis. The study identifies the causes of failure in English Language in secondary schools, the factors responsible for the inability of students to learn English language as a second language and the effect of mother tongue interference on the performance of students in English language in the study area. Data for this study were collected through the use of structured questionnaires. The data collected were analyzed using descriptive statistical tools. On the basis of the findings, the study suggested that English language teachers in secondary schools endeavour to avoid the use of vernacular in the teaching of English language. Also, well equipped libraries and other necessary materials that would assist the students in learning English language should be provided in all the secondary schools by the government.
\end{abstract}

Keywords: Language barrier, performance, mother tongue, interference, vernacular

\section{Introduction}

English language plays a very important role in Nigeria. Apart from being the official language, it is also the language of instruction in our institutions of learning. In a country like Nigeria where English language is the lingua franca, the barrier its learners face is a serious problem that should be investigated. This is why we cannot but link the failure of our students in their process of learning English with the challenge of language barrier.

A child who learns English at school but always speaks his mother tongue at home will seldom have occasions to discuss any topic in the English language at home and whenever he/she has the opportunity to do so, it will be difficult. Another challenge that confronts second language learning and teaching in our schools is lack of oral practice by the students in different language situations. However, second language learning problems arise from "interference". This means the effect of transferring the habits associated with the learners' own mother-tongue to the target language (second language). According to Tiffen (1968), “An English man learning Hausa language is likely to 'carry over' the phonetic, lexical and grammatical features of his own language when he speaks Hausa, in the same way that a Hausa man does when he speaks English".

Language barrier is a term used to imply all the problems faced by an individual as he tries to communicate with a group of people who speak a tongue other than his own. It is prevalent in settings which involve the conglomeration of people from different cultures, speaking different languages. It is also used as a blanket term for all the difficulties associated with the learning of a foreign language (Wikipedia, 2006).Over the years, there have been various steps taken by administrators in both, academic and business worlds, to eradicate or at least minimize this problem in English speaking environments by providing courses, workshops and training. Yet, this problem is persistent, if not widespread, in schools across the nation. With a thorough understanding of the situation, we hope to find a solution that will overcome this issue, and at the same time work best to help students find resources to be proficient in oral English.

All over the world, there is a growing interest in language as a communicative instrument. The incidence of the Second World War accentuated this interest. In America and Europe, the war brought about the urgent need to teach soldiers as many foreign languages as possible and by the fastest method feasible. There was the realization that competence in a second language depended mainly on the habitual manipulation of the sentence pattern of that language. There was the awareness that the time spent on traditional pronunciation rules and analysis was time wasted because those who could use a language were unable to recite its rules and those who could recite its rules could not use it. 
Wang, 2002 suggests that Language reflects culture and tends to control or influence processes used to think and to perceive. Thus, sometimes, the barriers are not due to the use of words in the language, but the ways the speakers speak or how the listeners perceive. In addition, cultures also shape the way students communicate with others. For example, Asian international students are particularly sensitive to the issue of "save face". In providing assistance or instruction to an Asian student, if the teacher asks the student, "Do you understand?", the student is likely to respond that he/she understands, even if he/she does not. Such an attitude would generate a barrier in communication.

Olagoke D.O (1979) explains that parents are naturally anxious that their children should become doctors, lawyers, engineers and so on; as such, parents in an attempt to make their children learn English early in life sacrifice a large part of their income in sending them to nursery and other fee-paying private schools, where they are usually taught by qualified and well paid teachers. As a result, children from such schools come home after one or two terms speaking good English. This is unlike what obtains in most of the government owned schools, where parents cannot provide their children with the required textbooks.

\subsection{Statement of Problem}

Language barrier is a major hindrance to the learning of English Language as a second language and this has had adverse effect on the performance of secondary school students in English language as a subject and as a means of communication. This therefore calls for drastic measures to be taken to save learners from the mass failure in English language in internal as well as external examinations like WASSCE, NECO, NABTEB, JAMB and JSCE examinations.

\subsection{Objectives of The Study}

The broad objective of this study is to assess Language barrier and the performance of students in English Language in secondary schools in Katsina Metropolis. The specific objectives are:

i. $\quad$ To identify the causes of failure in English Language in secondary schools; To identify the factors responsible for the students' inability to learn English as a second language ;

ii. To determine the effect of language barrier on the performance of the students in the target language and;

iii. To find out if the content of the English curriculum and the textbooks used embrace all the various aspects of the language that meet the needs of the learners.

\subsection{Research Questions}

In the light of the aforementioned, this research work seeks to answer the following questions:

I. To what extent does the use of vernacular in teaching help the students to learn the English Language better?

II. What are the factors responsible for the students' inability to learn English as a second language?

III. How has language barrier and mother tongue interference affected the performance of students in English Language?

IV. Does the content of the curriculum embrace all the various aspects of English language?

V. Do the textbooks used suit the needs of the learners of English in a multi-lingual setting as Nigeria?

VI. Are the students exposed to the use of appropriate teaching aids, materials and equipment for promoting English language learning?

VII. Beside the normal classroom teaching period, what are the extracurricular activities the learners are exposed to, to enhance their listening and communication skills?

VIII. Do the English teachers motivate the learners to communicate in English Language regularly?

IX. To what extent does the government employ qualified teachers and supply sufficient materials for the teaching of English Language in the secondary schools?

X. Does the government encourage the English Language teachers to advance their knowledge through in-service training?

\subsection{Significance of the Study}

The need for this study arose because little or no work had been done on the effect of language barrier on the performance of students in English Language in the study area. Likewise the performance of most students in Katsina metropolis in public examinations has been poor recently and the extent to which language barrier has affected the performance needed to be verified, so as to proffer solutions to this menace.

To achieve this however, all possible shortcomings likely to be confronted by the students in the process of learning English as a second language have to be identified. Also efforts have to be made to find solution to the problems identified. Therefore, it is the hope of the investigators that the outcome of this research will be of great help to the students, their teachers and the managers of secondary schools, in their efforts to help the students learn English as a second language.

Furthermore, this research hopes to be one of the useful guides to curriculum planners and educational administrators in selecting suitable materials for schools. For example, the planners should consider the important principles underlying second language in their planning. Such principles will help the curriculum planners to include a carefully selected and graded topic in the pronunciation of English words and other aspects of English speech relating to speaking for communication function such as dialogue and conversations, public speech, oral presentation of written materials like prose, poetry and news casting or announcements. 
Another significant aspect of this study is to make our educational administrators and inspectors see the need for constant and adequate inspection of our schools and for the purpose of evaluating their progress effectively. Furthermore, it is hoped that the findings from this work will contribute positively to the learning of English as a second language in Katsina Metropolis, Nigeria as a whole and other parts of the world.

\section{Literature Review}

Many people have done some studies in the area of mother tongue interference in learning English as a second language. All these studies agreed that the problem of interference is felt at the level of syntax, morphology and mostly phonology. Ubahakwe (1979) attempted to give a definition of interference problems faced by children learning English grammatical structure. He says, "There is considerable linguistic confusion and difficulty on the part of the child as he thinks in his mother tongue, but tries to express himself in foreign language". Considering the fact that there is a great difference between the sound system and lexical items of English and that of the mother tongue, thus transfer results in numerous errors.

Wilkins (1972) in his book, Linguistics in Language Teaching, discusses the problems of pronunciation in the teaching of English as a second language. He claims that students of English as a second language tend to make mistakes in pronunciation, speaking, vocabulary and grammar as a result of the interference of their mother tongues. He asserts, "If we look at the speech of the foreign learner, there is little reason to doubt that we will find many mistakes which can be traced back to the mother tongue". The learner in his attempt to produce utterance in foreign language is influenced not only by the sounds that exist in his mother tongue but also by their distribution and phonetic status. Morphological and syntactical systems are often transferred directly from the mother tongue to utterances in the foreign language.

In Contrastive Grammar and Textbook Structure in monograph series on languages and linguistics (1968), Hall states that when a speaker of language $A$ begins to learn language $B$, he is inevitably going to meet phenomena on all levels of linguistic structures and often in orthography as well, which are different from those which he is accustomed to in his mother tongue or first language and the target language is going to cause him difficulties which have to be overcome in one way or another during learning process.

According to Tiffen (1968) interference of one sort or the other is a general learning problem. Some other difficulties usually lie in the handling of English tenses, the use of countable and uncountable nouns, articles and prepositions. For example, the following are prepositions of English and Hausa as illustrated by Tiffen (1969) :

$\begin{array}{ll}\text { HAUSA } & \text { ENGLISH } \\ \text { darana } & \text { by day } \\ \text { da safe } & \text { in the morning } \\ \text { da dare } & \text { at night } \\ \text { dakafa } & \text { on foot } \\ \text { dahannu } & \text { by hand }\end{array}$

These Hausa and English equivalent prepositions present difficulty in selecting the correct one. Another problem which is common among any speakers in different parts of Africa is the problem of the correct answer to a negative question. For example,

\section{Hasn't he come? No (i.e he hasn't come), but in Hausa it would be: \\ Bai zoba?eeh, baizoba (i.e yes, he hasn't come).}

In this situation, Hausa uses 'yes', where English uses 'no'. Whereas Hausa yes/no refers to the accuracy of the form of the questions, English is concerned with the facts of the situation, hence the confusion. This problem will require drilling, if students are to make the correct automatic response in English.

Obanya, 1995 opines that a belief exists that African languages are not equipped to deal with scientific and technical concepts and many parents refuse to have their children learn a national language when they consider it to have been imposed for political rather than socio-linguistic or demographic considerations .And in the view of (Cazden, 2000), a problem not often addressed is the transition the students must make from using the home language to using the national language, and the lack of learning resources and teacher support which are needed to bridge this important linguistic gap .

There are certain social and emotional factors that influence the learning of a second language. These factors include:

(i) Differences in sex: This can be a factor in second language learning. Robinson (1971) quoted in Sanusi (2007) suggests that "being good at language may be seen as an admirable thing for girls but unmanly for boys". This may mean that second language learning is easier for girls than boys.

(ii) Age factors: This can also determine second language learning. Since second language learning is more formal in nature than the first language. The older the learner is experienced, the easier for them to learn.

(iii) The socio-economic :Trudgill (1974) and Mary Faith Mount-Cors (2008) believe that success or failure in language acquisition and competence depends largely on ones socio-economic class. 
Here the background information on the study area, sampling technique, data collection, choice of analytical tools and limitation to the study are provided.

\subsection{Area of Study}

Katsina State came into existence on September 23, 1987 as a result of creating another state out of the former Kaduna State by the Federal Government. The state has an area of approximately 24,192 square kilometres and it is bounded in the East by Kano and Jigawa states, in the West by Zamfara State, in the South by Kaduna State and in the North by Niger Republic. The state has thirty-four (34) local government areas with a population of about 5,792,578 (Federal Office of Statistics, 2006). The language spoken is Hausa.

\subsection{Data Collection}

The study used both secondary and primary data. The primary data for this study were collected with the help of a wellstructured questionnaire and personal interview with the students. The questionnaire was prepared in such a way that it adequately elicited relevant information from the students. The information collected covered all the necessary areas required for the achievement of the objectives of the research.

\subsection{Population}

The population of this research work from which the samples were selected included all the registered secondary schools in Katsina metropolis. They were thirty-four (34) and consisted nineteen (19) public (government) secondary schools and fifteen (15) private secondary schools. The population of students enrolled in all these thirty-four secondary schools in Katsina metropolis was approximately fifty thousand $(50,000)$ students.

\subsection{Sample Size and Sampling Technique}

A sample size of 100 participating students and 20 teachers in the selected schools was selected, using the simple randomized sampling technique. The purpose of the choice of this method was to give the respondents an equal and independent chance of being selected.

\subsection{Analytical Technique}

Information and data collected from the field were analyzed using descriptive statistical tools, such as percentages, frequency distribution tables, graphs and charts (Bar-chart and Pie-chart).

Percentage: is the proportion of the total observations multiplied by 100

Percentage $(\%)=$ individual observation $X 100$

Total number of observations

\subsection{Limitation of the Study}

This research work was not without some limitations as a result of the errors from different sources. Errors in data constituted the most serious limitation to the study. Other limitations include:

i. Constraint in getting the correct data from the students

ii. Measurement errors due to conversion of units

iii. Time constraint

iv. Unavailability of sufficient data

v. Communication barrier

\subsection{Research Hypotheses}

The research assumptions include:

i. Historically, the late introduction of western education in the northern parts of Nigeria is one of the factors that contributed to the slow progress in the learning of English as a second language in the study area.

ii. There are only few qualified English language teachers in the secondary schools in this area.

iii. The teachers do not use instructional materials in the teaching of English language.

iv. The teachers do not receive enough motivation from the government.

v. Parents as well as the environment where the students are living do not help in improving their pronunciation of English words.

vi. Students do not learn the English language outside the classroom.

iv. The schools do not have well equipped libraries and language laboratories.

v. The schools lack relevant English language texts.

3.8 Scope of the Study

The study is designed to cover Language Barrier and the Performance of students in English Language in selected Secondary Schools in Katsina Metropolis. The schools covered by this research include:

i. Government Day Secondary School, KofarSauri, Katsina

ii. Government Girls College, Katsina

iii. Government Day Secondary School, KofarYandaka, Katsina

iv. MariamohAjiri Memorial International School, Katsina

v. Hope International School, Katsina 


\section{Data Presentation And Analysis}

The result or findings of this research were analyzed in order to assess the validity of the earlier stated research questions.

\subsection{Result And Discussion}

This section presents the data collected from the field survey research. 100 questionnaires were administered to students and 20 to teachers, and all were completed and returned.

\subsection{The use of vernacular in teaching English Language}

Table 1. Do your teachers use vernacular to teach you English Language?

\begin{tabular}{lll}
\hline Variable & Frequency & Percentage (\%) \\
\hline Agreed & 31 & $31 \%$ \\
Not Agreed & 67 & $67 \%$ \\
Undecided & 02 & $02 \%$ \\
Total & 100 & $100 \%$ \\
\hline
\end{tabular}

The above table shows that $31 \%$ of the respondents agreed that their teachers used vernacular to teach them English Language, $67 \%$ said their teachers did not use vernacular, while $2 \%$ were undecided.

Table 2. Does the use of vernacular help you to speak or understand English language?

\begin{tabular}{lll}
\hline Variable & Frequency & Percentage (\%) \\
\hline Agreed & 42 & $42 \%$ \\
Not Agreed & 53 & $53 \%$ \\
Undecided & 05 & $05 \%$ \\
Total & 100 & $100 \%$ \\
\hline
\end{tabular}

The above table shows that $42 \%$ of the respondents agreed that the use of vernacular (e.g Hausa) helped them to understand English Language lessons, 53\% disagreed with this.

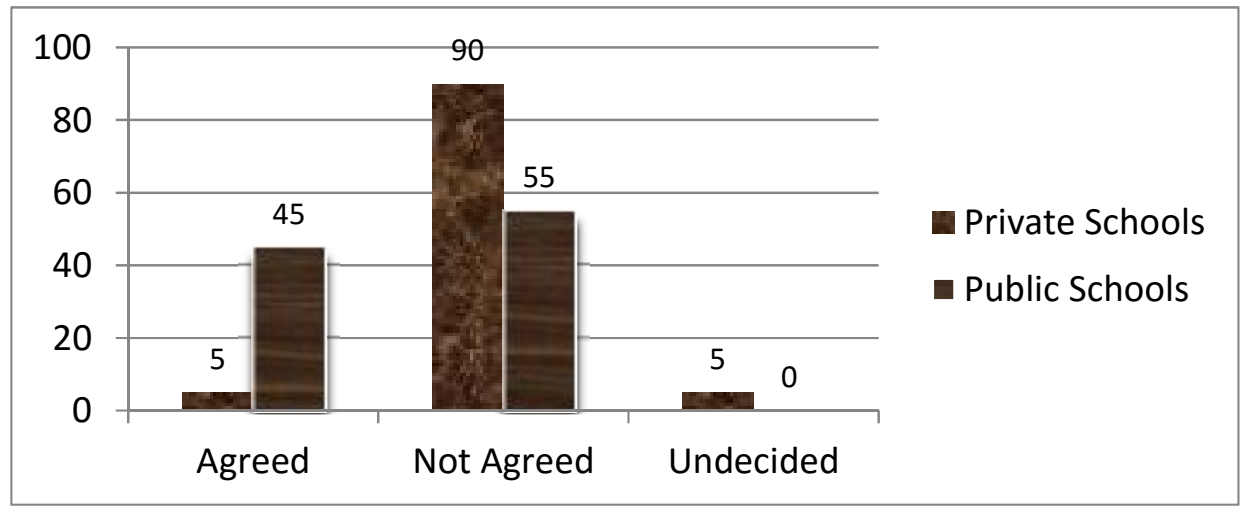

Figure 1. Use of vernacular to teach English

The figure above shows that $5 \%$ of the respondents from private schools agreed that their teachers used vernacular to teach them English Language in the class, 90\% said that their teachers did not use vernacular to teach them in class, while $5 \%$ were undecided. On the part of the public schools respondents, $45 \%$ agreed that their teachers used vernacular to teach them English language in class, while about 55\%disagreed with it. This is an indication that many of the English Language teachers in Public (government) schools used vernacular (e.g Hausa) to teach English Language during their lessons. 
Table 3. Do you find some English words difficult to pronounce due to your mother tongue interference?

\begin{tabular}{lll}
\hline Variable & Frequency & Percentage (\%) \\
\hline Agreed & 46 & $46 \%$ \\
Not Agreed & 47 & $47 \%$ \\
Undecided & 07 & $07 \%$ \\
Total & 100 & $100 \%$ \\
\hline
\end{tabular}

From the table above, $46 \%$ of the students interviewed agreed that they found some English words difficult to pronounce due to mother tongue interference, $47 \%$ did not find English words difficult to pronounce, while $7 \%$ were undecided.

Table 4. Mother tongue interference does affect the teaching and learning of English language.

\begin{tabular}{lll}
\hline Variable & Frequency & Percentage (\%) \\
\hline Agreed & 15 & $75 \%$ \\
Not Agreed & 05 & $25 \%$ \\
Undecided & 00 & $00 \%$ \\
Total & 20 & 100 \\
\hline
\end{tabular}

From the teachers interviewed, $75 \%$ believed that mother tongue interference did affect the teaching and learning of English Language, while $25 \%$ did not agree to this. This is an indication that mother tongue interference is one of the major factors affecting the learning of English as a second language.

Table 5. Language barrier has a negative effect on the performance of students in English language.

\begin{tabular}{lll}
\hline Variable & Frequency & Percentage (\%) \\
\hline Agreed & 17 & $85 \%$ \\
Not Agreed & 03 & $15 \%$ \\
Undecided & 00 & $00 \%$ \\
Total & 20 & $100 \%$ \\
\hline
\end{tabular}

The table above shows that about $85 \%$ of the teachers interviewed accepted that Language Barrier has a negative effect on the performance of students in English Language, while 15\% didnot accept.

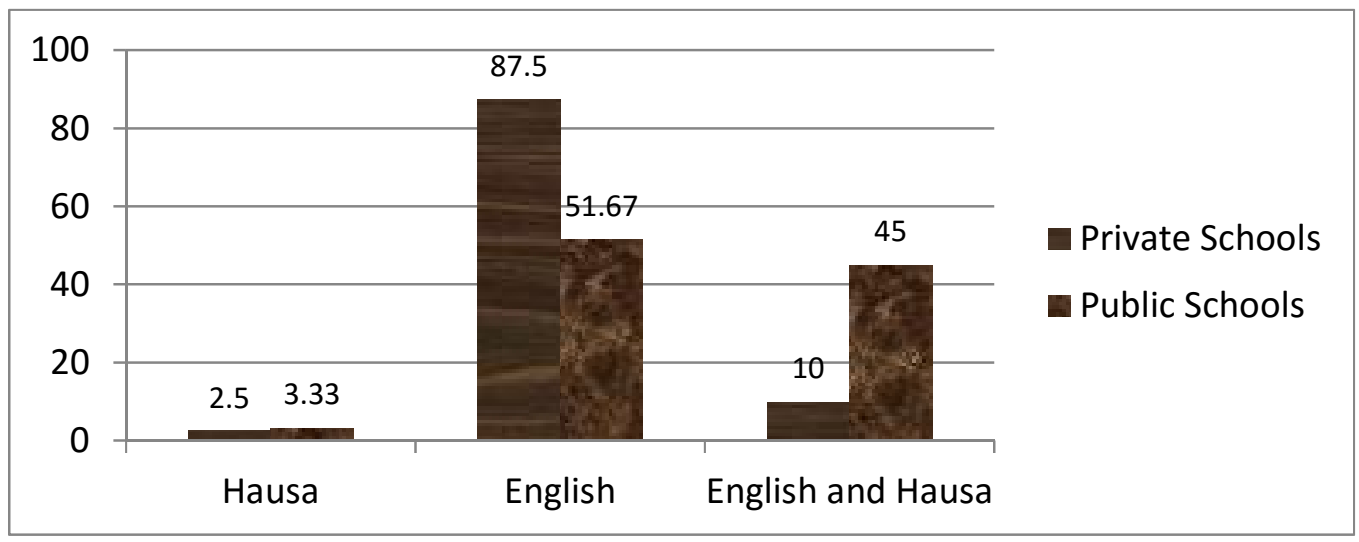

Figure 2. Use of Vernacular to teach English Language at the Primary School level

The chart above reveals that about $2.5 \%$ of the students in Private Schools said when they were in Primary school, their English teachers used Hausa language to teach them English language, 87.5\% said their teachers used English language 
to teach them English, while 10\% said their English teachers used both English and Hausa to teach them English. On the part of the respondents from the Public Schools, 3.33\% said when they were in Primary school, their English teachers used Hausa language to teach them English, 51.6\% said their teachers used English language, while 45\% said their teachers used both English and Hausa. This analysis shows that the use of vernacular (Hausa language) in the public primary schools to teach English language is one of the causes of poor performance of secondary school students in English language in the area.

Table 6. There are enough professional English teachers in your school.

\begin{tabular}{lll}
\hline Variable & Frequency & Percentage (\%) \\
\hline Agreed & 9 & $45 \%$ \\
Not Agreed & 11 & $55 \%$ \\
Undecided & 00 & $00 \%$ \\
Total & 20 & $100 \%$ \\
\hline
\end{tabular}

From the questionnaire administered to the teachers, $45 \%$ agreed that there were enough professional English language teachers in the secondary schools, while $55 \%$ disagreed.

4.4 Performance of students in English language

Table 7. How was your performance in English language last term?

\begin{tabular}{lll}
\hline Variable & Frequency & Percentage (\%) \\
\hline Excellent & 44 & $44 \%$ \\
Good & 36 & $36 \%$ \\
Average & 12 & $12 \%$ \\
Below average & 08 & $08 \%$ \\
Total & 100 & $100 \%$ \\
\hline
\end{tabular}

From the 100 students that were sampled, the table above shows that $44 \%$ performed excellently in English language in the previous term, $36 \%$ performance were good, $12 \%$ performed averagely, while $8 \%$ performed below average.

\subsection{The content of the English language curriculum}

Table 8. English language curriculum contains the various aspects of English language that suit the needs of the learners of English as a second language.

\begin{tabular}{lll}
\hline Variable & Frequency & Percentage (\%) \\
\hline Agreed & 15 & $75 \%$ \\
Not Agreed & 04 & $20 \%$ \\
Undecided & 01 & $05 \%$ \\
Total & 20 & $100 \%$ \\
\hline
\end{tabular}

Out of the 20 teacher respondents, 75\% believed that the English language curriculum contained all the various aspects of English language that would suit the needs of the learners of English as a second language, 20\% disagreed, while 5\% were undecided.

4.6 Suitability of the English language textbooks in used.

Table 9. The textbooks used in our secondary schools suit the needs of the learners of English as a second language in a multi-lingual setting like Nigeria.

\begin{tabular}{lll}
\hline Variable & Frequency & Percentage (\%) \\
\hline Agreed & 08 & $40 \%$ \\
Not Agreed & 10 & $50 \%$ \\
Undecided & 02 & $10 \%$ \\
Total & 20 & $100 \%$ \\
\hline
\end{tabular}


On the suitability of the English textbooks used, $40 \%$ of the teachers believed that the English textbooks in use were suitable to meet the needs of the learners of English as a second language in a multi-lingual setting as Nigeria, 50\% disagreed with this view, while $10 \%$ were undecided.

Table 10. Do your students have English language textbooks?

\begin{tabular}{lll}
\hline Variable & Frequency & Percentage (\%) \\
\hline YES & 07 & $35 \%$ \\
NO & 13 & $65 \%$ \\
Total & 20 & $100 \%$ \\
\hline
\end{tabular}

The table above shows that $35 \%$ of the teacher respondents said their students had English language textbooks, while $65 \%$ said their students did not have. From the survey in this research, it was observed that all the respondents that said their students had English language textbooks were from private schools. This implies that majority of the students in public (government) schools did not have the English language textbooks, which consequently affected their ability to learn English as a second language.

4.7 Availability of a well-equipped library, teaching aids and equipment for enhancing English language learning

Table 11. There is a well equipped library in your school.

\begin{tabular}{lll}
\hline Variable & Frequency & Percentage (\%) \\
\hline Agreed & 05 & $25 \%$ \\
Not Agreed & 11 & $55 \%$ \\
Undecided & 04 & $20 \%$ \\
Total & 20 & $100 \%$ \\
\hline
\end{tabular}

On the aspect of availability of a well-equipped library in the schools, $25 \%$ of the teachers said they had a wellequipped library, $55 \%$ said they did not have, while $20 \%$ were undecided. On comparing the private and the public schools, it was discovered that $37.5 \%$ of the teachers from the private schools said they had well-equipped libraries in their schools, 25\% said they did not have, while 37.5 were undecided. On the part of the respondents from the public schools, $16.67 \%$ of the teachers said they had well equipped libraries in their schools, $75 \%$ said they did not have, while $8.33 \%$ were undecided.

Table 12. Your teachers use other teaching aids apart from English textbooks during English language lessons.

\begin{tabular}{lll}
\hline Variable & Frequency & Percentage (\%) \\
\hline Agreed & 45 & $45 \%$ \\
Not Agreed & 50 & $50 \%$ \\
Undecided & 04 & $05 \%$ \\
Total & 100 & $100 \%$ \\
\hline
\end{tabular}

$45 \%$ of the respondents said that their teachers used other teaching aids apart from English textbooks during English language lessons, $50 \%$ disagreed with this, while $5 \%$ were undecided.

Table 13. Which television or radio programme do you watch/listen to often?

\begin{tabular}{lll}
\hline Variable & Frequency & Percentage (\%) \\
\hline English only & 27 & $27 \%$ \\
Hausa only & 08 & $08 \%$ \\
English and Hausa & 59 & $59 \%$ \\
None of the above & 06 & $06 \%$ \\
Total & 100 & $100 \%$ \\
\hline
\end{tabular}

From the table above, $27 \%$ of the respondents said the television/radio programmes they watched/listened to often were in English only, 8\% said they watched/listened to Hausa programmes only, 59\% watched/listened to both English and Hausa programmes, while $6 \%$ said none of the above. 
Table 14: Do you have a literary and debating club in your school?

\begin{tabular}{lll}
\hline Variable & Frequency & Percentage (\%) \\
\hline YES & 76 & $76 \%$ \\
NO & 19 & $19 \%$ \\
No Response & 05 & $05 \%$ \\
Total & 100 & $100 \%$ \\
\hline
\end{tabular}

The table above shows that $76 \%$ of the respondents said they had a literary and debating club in their schools, $19 \%$ said they did have any, while $5 \%$ did not respond to the question.

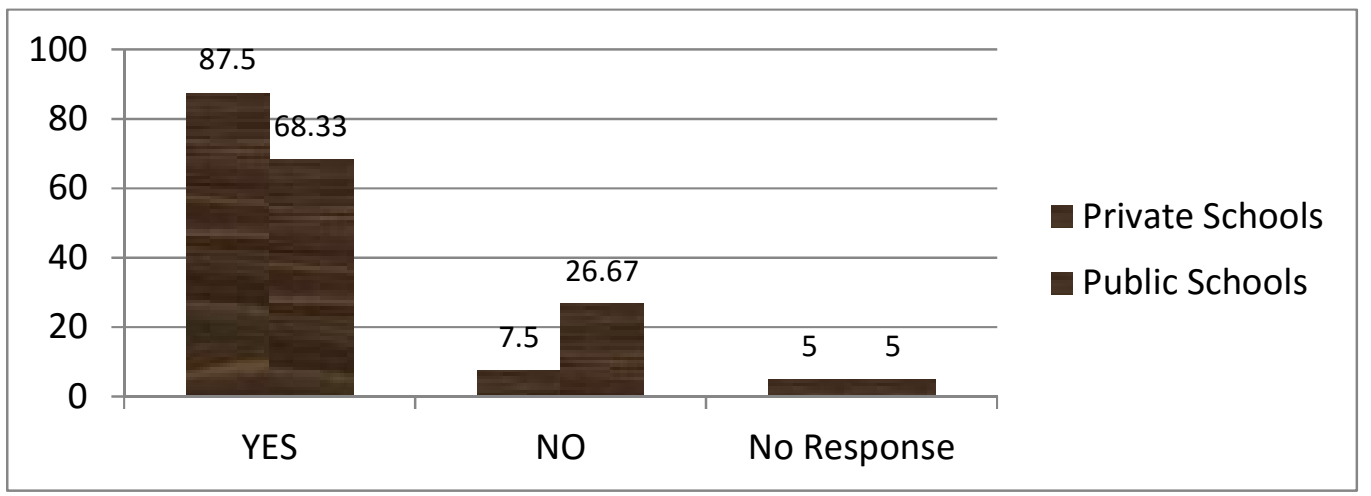

Figure 3. Availability of literary and debating clubs in the school

Comparing the private and the public schools, the figure below shows that about $87.5 \%$ of the respondent from private schools said they did have literary and debating clubs, $7.5 \%$ said they did not have any, while $5 \%$ did not respond. On the part of the public school respondents, $68.33 \%$ of the respondents said they had, $26.67 \%$ said they did not have, while $5 \%$ did not respond to the question.

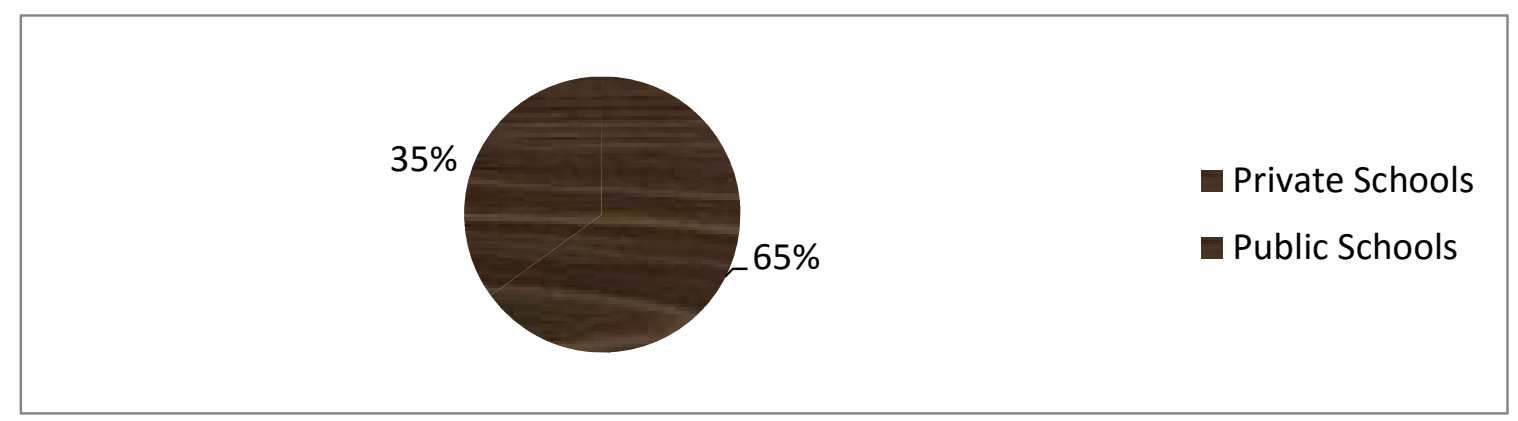

Figure 4. Availability of extracurricular activities in the school

The figure above shows that about $65 \%$ of the respondents from private schools said they did have extracurricular activities like group discussions, debate, quiz, speech presentation, news casting, drama, spelling competition and storytelling which helped them to improve on their English language, while $35 \%$ of the respondents from public schools said they did not have such activities. This implies that most of the public (government) schools did not organise social and intellectual activities to facilitate the learning English language.

\subsection{Motivation received by the students from their teachers}

Table 15. Does your English language teacher encourage you to speak English in the class?

\begin{tabular}{lll}
\hline Variable & Frequency & Percentage (\%) \\
\hline YES & 93 & $93 \%$ \\
NO & 03 & $03 \%$ \\
No Response & 04 & $04 \%$ \\
Total & 100 & $100 \%$ \\
\hline
\end{tabular}


About $93 \%$ of the student respondents said that their English teachers encouraged them to communicate in English in the class, $3 \%$ said their teachers did not encourage them to do so, while $4 \%$ did not respond.

4.9 The role of government in supporting the learning of English language

Table 16. Government provides sufficient materials for teaching English language in your school.

\begin{tabular}{lll}
\hline Variable & Frequency & Percentage (\%) \\
\hline Agreed & 01 & $05 \%$ \\
Not Agreed & 17 & $85 \%$ \\
Undecided & 02 & $10 \%$ \\
Total & 20 & $100 \%$ \\
\hline
\end{tabular}

From the teacher respondents, 5\% said that government provided sufficient materials for the teaching English language in the secondary schools, $85 \%$ said that government did not provide sufficient materials, while $10 \%$ were undecided.

Table 17. Do you agree that the English language teachers employed in our secondary schools are qualified?

\begin{tabular}{lll}
\hline Variable & Frequency & Percentage (\%) \\
\hline Agreed & 13 & $65 \%$ \\
Not Agreed & 05 & $25 \%$ \\
Undecided & 02 & $10 \%$ \\
Total & 20 & $100 \%$ \\
\hline
\end{tabular}

From the teachers' questionnaires administered, $65 \%$ of the teachers agreed that government employed qualified English language teachers, $25 \%$ disagreed, while $10 \%$ were undecided.

\subsection{Professional development on the part of the English language teachers}

Table 18. Have you attended any seminar, workshops or conferences?

\begin{tabular}{lll}
\hline Variable & Frequency & Percentage (\%) \\
\hline YES & 18 & $90 \%$ \\
NO & 02 & $10 \%$ \\
Total & 20 & $100 \%$ \\
\hline
\end{tabular}

About $90 \%$ of therespondents said they attended seminars, workshops and conference one time or the other, while $10 \%$ said they did not have such opportunities.

Table 19. Have you ever applied for in-service training?

\begin{tabular}{lll}
\hline Variable & Frequency & Percentage (\%) \\
\hline YES & 06 & $30 \%$ \\
NO & 14 & $70 \%$ \\
Total & 20 & $100 \%$
\end{tabular}

The table above shows that about $30 \%$ of the teachers applied for in-service training in the past, while $70 \%$ never applied for in-service training. It was discovered during the course of this research that majority of the teachers who never applied for in-service training were from the private schools. This might be because permission would not be granted or the teachers themselves were not prepared to further their education.

\section{Summary Recommendations And Conclusion}

\subsection{Summary of major findings}

This research work was carried out to assess Language Barrier and the Performance of students in English Language in secondary schools in Katsina Metropolis. The data used in this research work were all collected through the use of questionnaire (primary data) from five secondary schools (both private and public) within Katsina Metropolis. The analytical tools used were descriptive statistical tools, such as percentages, frequency distributions tables, bar-charts and pie-chart. The results obtained showed that majority of the teachers in public (government) schools used vernacular (e.g 
Hausa) to teach their students English language lessons, while reverse is the case in most private schools. About $53 \%$ of the students said the use of vernacular to teach English language did not help them understand English language lessons, while $42 \%$ of the students said it helped them.

The use of vernacular (Hausa language) in public primary schools to teach English language is one of the causes of poor performance of secondary school students in English language in most of the public schools. This study showed that about $2.5 \%$ of the students in Private Schools said when they were in Primary school, their English teachers used Hausa language to teach them English language, while 87.5\% said their teachers used English language to teach them English; but on the part of the respondents from the Public Schools, 3.33\% said their English teachers used Hausa language to teach them English, while 51.6\% said their teachers used English language.

Some of the other factors responsible for the inability of students to learn English language include the fact that some of the learners of English language found some English words difficult to pronounce due to mother tongue interference. The other one is the negative effect of Language barrier on the performance of students in English language.

Also, the lack of professional English language teachers in the secondary schools is one of the factors responsible for the inability of the learner to learn English language, since the teachers play a vital role in the teaching-learning process. Likewise, about $75 \%$ of the teacher respondents believed that the content of the English language curriculum contains all the aspect $\mathrm{s}$ of English language that would suit the needs of the learners of English. This shows that the curriculum was not the problem. On the other hand, majority of the teachers agreed that the English language textbooks in use in the secondary schools were not suitable for the learners of English and that majority of the students (mostly those in public schools) did not have English language textbooks.

The lack of a well-equipped library and organization of social and intellectual activities like press club, quiz, debate, spelling competition, et cetera, in most of the public secondary schools are also other factors responsible for the inability of the learners of English as a second language to learn well. And in line with this was the lack of other appropriate teaching aids.

\subsection{Policy Recommendations}

The following recommendations are suggested by the researchers in order to improve the productivity of teachers in secondary schools in Katsina metropolis:

i. English language teachers should endeavour to avoid the use of vernacular in the teaching of English language.

ii. Teachers in primary schools should help the educational system by making sure they lay a solid foundation in spoken and written English.

iii. School administrators, both in the private and public schools, should endeavour to supervise their English language teachers while they are teaching in the class to make sure they communicate in English language.

iv. Both parents and teachers should encourage the learners to communicate in English language both within and outside the school.

v. English language teachers should endeavour to drill their students on the pronunciation and ensure they give them sufficient class work and assignments that would help to improve their English language skills.

vi. Since the teachers play a vital role in the teaching-learning process, teachers that are not professionals should endeavour to undergo professional training .

vii. Those involved in the production of English language textbooks should ensure all the necessary aspects of English language are included to help learners learn efficiently.

viii. On the part of our parents, they should make sure they purchase English language textbooks for their children and wards as this will help them improve in their studies.

ix. Well equipped libraries should be established in all the secondary schools by the government.

x. English language teachers in the secondary schools should endeavour to make use of other teaching aids to help the learners learn better. They should also organize extracurricular activities for the students to enhance their learning of English.

\subsection{Conclusion}

The use of vernacular to teach English language in secondary schools has done more harm than good to the learners of English language in Katsina metropolis. It is contributory to the poor performance of secondary school students in English language in most of the terminal examinations.

The content of the English language curriculum is not a problem but lack of suitable English language texts and wellequipped libraries is an impediment to effective teaching and learning of English in this area. Also, the absence of extracurricular activities like press club, quiz, debate, spelling competition, et cetera, hampers the learning of the language. And in line with this, is the failure of English language teachers to use appropriate teaching aids to illustrate their lessons and concretize learning. It is hoped that if the recommendations above are considered, the teaching and learning of English in Katsina metropolis will receive a boost and the learners' performance will no doubt be high. 


\section{References}

Cazden, C. B. (2000).Bilingual Education. State University: com/page/1788/Bilingual-Education.html.

Ebo, U. (1979).Varieties and Functions of English in Nigeria.Nigeria: Africa University Press.

Federal Office of Statistics, 2006.

Hall, E.T.(1968). Monograph Series on Language and Linguistics.

Mary, F. (2008). The middle school challenge for English language learners of Mexican origin. Mexico.

Obanya, P. (1995). Popular Fallacies on the use of African Languages in Education. Nigeria:MacmillanPublishersLtd.

Olagoke, D.(1979). The Usage of English Conjuncts by students in selected tertiary institutions.Academic press.

Tiffen, W. (1968). Teaching Speaking Skills among Second Language Learners. Unillorin.edu.ng

Tiffen, W. (1969).Language in Common: Guide to English Language Teaching in Schools and Colleges.Longman Group Ltd.

Trudgill, P. (1974). The Social differentiation of English in Norwich. Norwich:CUP Archive.

Sanusi, S. (2007).The Influence of Environment on the learning of English as a Second Language in Katsina State.(Unpublished Research Project), F.C.E., Katsina

Retrieved, (Tuesday, 17/01/2012). http://countrystudies.us/nigeria/37.htm

Retrieved, (Tuesday, 17/01/2012). http://www.mongabay.com/reference/ country studies/nigeria/SOCIETY.html

Retrieved, http://en.wikipedia.org/wiki/ (2006).

Retrieved April 19, 2006 from http://en.wikipedia.org/wiki/Language_barrier.

Wang, J. , Frank, D.G. (2002).Cross-Cultural Communication: Implications for Effective Information Services in Academic Libraries.

Wikipedia, (2006).Language Barrier.

Wilkins, A. (1972).Linguistics in Language Teaching.Cambridge:MIT Press.

\section{APPENDIX}

\section{RESEARCH QUESTIONNAIRE}

Dear Respondent,

Please fill in the gaps or $(\checkmark)$ where applicable

\section{SECTION A: Demographic Variables}

1) School:

2) Qualification: (a) G II $\quad$ (b) NCE $\quad$ (c) Degree $\quad$ (d) Others (specify)

3) Age: (a) $15-25$ years (b) $26-35$ years (c) $36-45$ years (d) 46 years and above

4) Years of experience on the Teaching profession
(a) $1-5$ years
(b) $6-12$ years (c) $13-25$ years
(d) $26-35$ years

5) Gender (a) Male (b) Female

\section{TEACHERS' QUESTIONNAIRE}

6) Do you use vernacular (Hausa) in teaching English Language?
(a) Agreed
(b) Not agreed
(c) Undecided

7) The use of vernacular (e.g. Hausa) helps students to understand English language lessons.
(a) Agreed
(b) Not agreed
(c) Undecided

8) Mother tongue interference does affect the teaching and learning of English language.
(a) Agreed
(b) Not agreed
(c) Undecided

9) Language barrier has a negative effect on the performance of students in English language.
(a) Agreed
(b) Not agreed
(c) Undecided

10) There are enough professional English teachers in your school.
(a) Agreed
(b) Not agreed
(c) Undecided 
11) The Englishlanguage curriculum contains the various aspects of English language that suit the needs of the learners of English as a second language.
(a) Agreed
(b) Not agreed
(c) Undecided

12) The textbooks used in our secondary schools suit the needs of the learners of English as a second language in a multi - lingual setting like Nigeria.
(a) Agreed
(b) Not agreed
(c) Undecided

13) Do your students have English language textbooks?
(a) Yes
(b) No

14) There is a well - equipped language library in your school.
(a) Agreed
(b) Not agreed
(c) Undecided

15) Do you use other teaching aids apart from textbooks during your English lesson?
(a) Yes
(b) No

16) The government provides sufficient materials for teaching English language in your school.
(a) Agreed
(b) Not agreed
(c) Undecided

17) Do you agree that the English language teachers employed in the secondary schools are qualified?
(a) Agreed
(b) Not agreed
(c) Undecided

18) Have you attended any seminar, workshops or conferences?

(a) Yes (b) No

19) If yes, how many times have your attended such workshops?
(a) $1-3$ (b) $4-6$ (c) $7-9$

20) Have you ever applied for in - service training?
(a) Yes
(b) No

21) If yes, were you granted the permission?
(a) Yes
(b) No

\section{SECTION 'B': STUDENTS' QUESTIONNAIRE}

1) Class:

2) Gender: (a) Male (b) Female

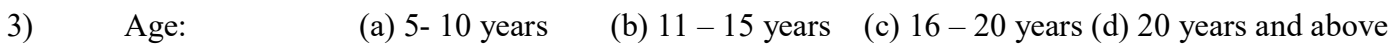

4) What is the occupation of your father or guardian?

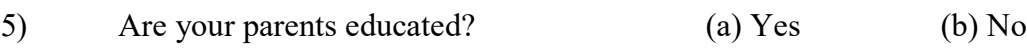

6) Do your teachers use vernacular (e.g. Hausa) to teach you English Language Subject?
(a) Agreed
(b) Not agreed
(c) Undecided

7) Does the use of vernacular help you to speak or understand English language?
(a) Agreed
(b) Not agreed
(c) Undecided

8) Do you find some English words difficult to pronounce due to your mother tongue interference ?
(a) Agreed
(b) Not agreed
(c) Undecided

9) When you were in primary school, which language did your teachers use in teaching you English language?
(a) Hausa
(b) English
(c) English and Hausa

10) Do you speak English outside the school environment?

(a) Yes (b) No

11)

Do your parents provide English language textbooks for you?

(a) Yes

(b) No

12) How was your performance in English language last term?
(a) Excellent
(b) Good
(c) Average
(d) Below average

13) What was your score out of 100 percent in English language last term?

14) There is a well equipped library in your school.
(a) Agreed
(b) Not agreed
(c) Undecided

15) Your teachers use other teaching aids apart from English textbooks during English language lessons.
(a) Agreed
(b) Not agreed
(c) Undecided 
16) Which television or radio programme do you watch/listen to often?
(a) English only (b) Hausa only (c) English and Hausa
(d) None of the above

17) Do you have a literary and debating club in your school?

(a) Yes (b) No

18) What are some of the social and intellectual activities organized by your teacher?

19) Does your English language teacher encourage you to speak English in the class?(a) Yes (b) No 